\title{
Pertumbuhan dan Produksi Buncis Tegak (Phaseolus vulgaris) pada beberapa Kombinasi Media Tanam Organik
}

\section{Growth and Production of Erected Kidney Bean (Phaseolus vulgaris L.) in some Combination of Organic Plant Growth Media}

\author{
Meilya Ramadhiana Safitry ,Juang Gema Kartika*
}

Departemen Agronomi dan Hortikultura, Fakultas Pertanian, Institut Pertanian Bogor (Bogor Agricultural University), J1. Meranti, Kampus IPB Darmaga, Bogor 16680, Indonesia

Telp.\&Faks.62-251-8629353 e-mail agronipb@indo.net.id

\begin{abstract}
Media selestion is one of important factor for the growth and production of erected kidney bean (Phaseolus vulgaris L.). Utilization the waste media of white oyster mushroom (Pleurotus ostreatus) and waste media of paddy straw mushroom (Volvariella volvaceae), cow manure, and rice husk as plant growth media for kidney bean can be used for optimizing the utilization of local resources and minimizing environmental damage as well as to support the codification of GAP (Good Agricultural Practices) of kidney bean. The research was done from February until October 2011 in experiment field at Leuwikopo, IPB, Bogor. The experiment consisted of one factor and arranged in Randomized Complete Design with thirteen combinations from five kinds of organic media component, they were soil, waste media of white oyster mushroom, waste media of paddy straw mushroom, cow manure, and rice husk with 1:1 ratio $(v / v)$. The kidney bean showed good responses to the combination media treatment of cow manure, combination of soil and waste media of paddy straw mushroom, combination of soil, waste media of paddy straw mushroom, and cow manure, and combination of soil, waste media of paddy straw mushroom, cow manure, and rice husk. How ever the best result of kidney bean production was given from waste media of paddy straw mushroom treatment.
\end{abstract}

Keyword: erected kidney bean, plant growth media, waste media of paddy straw mushroom, cow manure

\section{ABSTRAK}

Pemilihan media tanam merupakan salah satu faktor penting untuk pertumbuhan dan produksi kacang buncis (Phaseolus vulgaris L.). Pemanfaatan limbah media jamur tiram putih (Pleurotus ostreatus) dan limbah media jamurjerami padi (Volvariella volvaceae), pupuk kandang sapi, dan sekam padi sebagai media pertumbuhan tanaman untuk kacang buncis dapat digunakan untuk mengoptimalkan pemanfaatan sumber daya lokal dan meminimalkan kerusakan lingkungan serta mendukung kodifikasi GAP (Good Agricultural Practices) kacang buncis. Penelitian ini dilakukan dari bulan Februari sampai Oktober 2011 di kebun Percobaan Leuwikopo, IPB, Bogor. Percobaan menggunakan Rancangan Acak Lengkap satu faktor berupa kombinasi tiga belas dari lima jenis komponen media organik, yaitu tanah, media limbah jamur tiram putih, media limbah jamur jerami padi, kotoran sapi, dan sekam padi dengan rasio 1:1 (v/v). Kacang buncis menunjukkan respon yang baik terhadap perlakuan kombinasi media, yaitu pupuk kandang sapi, kombinasi tanah dan limbah media jamur jerami padi, kombinasi tanah, limbah media jamur jerami padi, pupuk kandang kotoran sapi, dan kombinasi tanah, limbah media jamur merang padi, kotoran sapi, dan sekam padi, tetapi hasil terbaik dari produksi kacang diberikan dari perlakuan limbah media jamur merang padi.

Kata kunci: $\quad$ kacang buncis, media pertumbuhan tanaman, limbah media jamur jerami padi, pupuk kandang sapi

\footnotetext{
* Penulis untuk korespondensi. e-mail: ika juang@yahoo.com
} 


\section{PENDAHULUAN}

Usaha tani sayuran pada saat ini telah banyak menggunakan input bahan kimia sintetik, baik pupuk maupun pestisida anorganik. Salah satu alternatif usaha pertanian yang ramah lingkungan adalah LEISA (Low External Input Sustainable Agriculture). LEISA merupakan suatu acuan bentuk pertanian untuk mengoptimalkan pemanfaatan sumberdaya lokal dengan kombinasi komponen sistem usaha tani yang sinergistik serta pemanfaatan input luar sebagai pelengkap untuk meningkatkan efektivitas sumber daya dan meminimalkan kerusakan lingkungan (Asandhi et al., 2005). Karakteristik fisik dan kimia media tanam menjadi salah satu penentu produktivitas dan mutu hasil panen dalam usaha tani LEISA sayuran. Hal tersebut berkaitan dengan pengaruh sifat dan ciri jenis input produksi yang dipakai dalam proses produksi. Ciri-ciri media tanam dan jenis input produksi ini perlu dikarakterisasi untuk mengoptimalkan pertumbuhan dan produksi tanaman sebagai bentuk kegiatan usaha tani LEISA yang menguntungkan.

Media tanam merupakan salah satu faktor penting dalam lingkungan hidup tanaman yang menjadi tempat tumbuhnya. Media tanam yang sesuai, baik media tanam tunggal maupun campuran, sangat menunjang pertumbuhan dan produksi tanaman karena dapat menyediakan air dan unsur hara serta menyangga keseluruhan tanaman. Tanaman yang tumbuh dalam wadah memiliki ketersediaan air yang kurang dan unsur hara serta drainase yang terbatas (Dole dan Wilkins, 2005).

Usaha pemanfaatan limbah pertanian dapat dilakukan sebagai bentuk optimalisasi pemanfaatan sumberdaya lokal dan untuk meminimalkan kerusakan lingkungan. Salah satu bentuk usaha tersebut yaitu dengan memanfaatkan limbah media tanam jamur tiram putih (Pleurotus ostreatus) dan limbah media tanam jamur merang (Volvariella volvaceae) sebagai media tanam. Selama ini limbah media tanam jamur tiram baru dimanfaatkan sebagai pakan ternak (Yuliastuti dan Susilo, 2003), media budidaya cacing Pheretima Sp. (Nurwati, 2011), bahan baku etanol, dan didaur ulang menjadi media tanam jamur tiram kembali, sedangkan limbah media tanam jamur merang belum dimanfaatkan secara intensif. Beberapa limbah pertanian lainnya yang dapat dimanfaatkan sebagai media tanam organik adalah arang sekam dan kotoran sapi.

Salah satu sayuran sumber protein nabati yang banyakdikonsumsimasyarakat Indonesiaadalah buncis. Berdasarkan data dari Badan Pusat Statistik Republik Indonesia (2011), pada tahun 2008 produktivitas buncis mencapai 8.52 ton ha $^{-1}$. Kemudian pada tahun 2009 produktivitas buncis mengalami peningkatan menjadi 9.48 ton $\mathrm{ha}^{-1}$, namun pada tahun 2010 produktivitas buncis mengalami sedikit penurunan menjadi 9.22 ton $\mathrm{ha}^{-1}$. Kondisi tersebut mendorong perlunya usaha peningkatan produktivitas buncis melalui budidaya pertanian dengan mengoptimalkan sumberdaya lokal yang ada.

Buncis tegak (Phaseolus vulgaris L.) merupakan tanaman sayuran varietas unggul dari Balai Peneltian Tanaman Sayuran (Balitsa). Buncis tegak memiliki habitus tanaman yang tegak, tidak seperti buncis rambat yang memiliki habitus merambat. Media tanam terbaik untuk budidaya buncis tegak masih perlu dicari guna mencapai potensi produksi yang optimal. Penelitian ini dilakukan untuk menunjang penyusunan GAP (Good Agricultural Practices) buncis tegak. Penelitian ini bertujuan untuk mengetahui pengaruh kombinasi media tanam serta korelasi sifat fisik dan kimia media tanam terhadap produksi buncis tegak.

\section{BAHAN DAN METODE}

Penelitian ini dilaksanakan di Kebun Percobaan Leuwikopo, Institut Pertanian Bogor, Dramaga, Bogor. Lokasi ini memiliki ketinggian tempat $240 \mathrm{~m}$ di atas permukaan laut. Penelitian ini dilaksanakan pada bulan Februari sampai Oktober 2011. Analisis tanah dan media tanam dilakukan di Laboratorium Tanah, Departemen Ilmu Tanah dan Sumberdaya Lahan, Fakultas Pertanian, Institut Pertanian Bogor.

Bahan yang digunakan pada penelitian ini adalah benih buncis tegak (Phaseolus vulgaris L.) nomor introduksi Le 02, limbah media tanam jamur tiram, limbah media tanam jamur merang, pupuk kandang sapi, arang sekam, tanah, dan bahan- bahan untuk pemeliharaan tanaman (pupuk urea $62 \mathrm{~kg} \mathrm{ha}^{-1}$, pupuk SP36 $250 \mathrm{~kg} \mathrm{ha}^{-1}$, pupuk $\mathrm{KCl} 90 \mathrm{~kg} \mathrm{ha}^{-1}$, pupuk NPK Mutiara) serta bahan-bahan untuk analisis media tanam.

Rancangan percobaan yang digunakan adalah Rancangan Kelompok Lengkap Teracak (RKLT) faktor tunggal, yaitu kombinasi media tanam dengan 13 taraf perlakuan berdasarkan volume per volume (v/ v).

Data yang diperoleh dianalisis menggunakan sidik/analisis ragam. Hasil yang berpengaruh nyata diujilanjut dengan uji Duncan Multiple Range Test (DMRT) pada taraf $5 \%$. Perlakuan percobaan terdiri atas 13 taraf perlakuan kombinasi media tanam berdasarkan volume, yaitu: 


$$
\begin{aligned}
\mathrm{P} 1= & \text { tanah }(100 \%) \\
\mathrm{P} 2= & \text { limbah media jamur tiram }(100 \%) \\
\mathrm{P} 3= & \text { limbah media jamur merang }(100 \%) \\
\mathrm{P} 4= & \text { pupuk kandang sapi }(100 \%) \\
\mathrm{P} 5= & \text { tanah }+ \text { limbah media jamur tiram }(1: 1) \\
\mathrm{P} 6= & \text { tanah }+ \text { limbah media jamur merang } \\
& (1: 1) \\
\mathrm{P} 7= & \text { tanah }+ \text { limbah media jamur tiram }+ \\
& \text { pupuk kandang sapi }(1: 1: 1) \\
\mathrm{P} 8= & \text { tanah }+ \text { limbah media jamur tiram }+ \text { arang } \\
& \text { sekam }(1: 1: 1) \\
\mathrm{P} 9= & \text { tanah }+ \text { limbah media jamur tiram }+ \text { pupuk } \\
& \text { kandang sapi }+ \text { arang sekam }(1: 1: 1: 1) \\
\mathrm{P} 10= & \text { tanah }+ \text { limbah media jamur merang }+ \\
& \text { pupuk kandang sapi }(1: 1: 1) \\
\mathrm{P} 11= & \text { tanah }+ \text { limbah media jamur merang }+ \\
& \text { arang sekam }(1: 1: 1) \\
\mathrm{P} 12= & \text { tanah }+ \text { limbah media jamur merang } \\
& + \text { pupuk kandang sapi }+ \text { arang sekam } \\
& (1: 1: 1: 1) \\
\mathrm{P} 13= & \text { tanah }+ \text { limbah media jamur tiram }+ \\
& \text { limbah media jamur merang }+ \text { pupuk } \\
& \text { kandang sapi }+ \text { arang sekam }(1: 1: 1: 1: 1)
\end{aligned}
$$

Perlakuan P1 hingga P4 merupakan komponen media tanam tunggal, sedangkan perlakuan P5 hingga P13 merupakan komponen media tanam campuran dari berbagai macam media tanam tunggal.

Setiap taraf perlakuan diulang tiga kali sehingga terdapat 39 satuan percobaan. Setiap satuan percobaan terdiri dari 10 polibag (disebut petak percobaan). Masing - masing polibag ditanami 2 benih.Total populasi tanaman buncis tegak adalah 780 tanaman. Tanaman contoh yang diamati sebanyak 5 polibag yang dipilih secara acak setiap perlakuan, sehingga terdapat 195 polibag tanaman contoh.

Media tanam yang telah diperoleh dikeringanginkan terlebih dahulu kemudian diayak agar mudah digunakan sebagai media tanam. Pada perlakuan media tanam tunggal, komponen media tanam yang telah diayak langsung dimasukkan ke dalam masing-masing polibag dengan ukuran 1 polibag = 1 volume ember (ember berukuran $8 \mathrm{~L}$ ). Pada perlakuan media tanam campuran, masing - masing komponen media tanam dicampur rata terlebih dahulu sesuai dengan perbandingan media tanam pada setiap perlakuan kemudian dimasukkan ke dalam polibag. Setiap perlakuan terdapat 30 polibag, sehingga media tanam yang diperlukan tiap perlakuan sebanyak 30 volume ember.

Penanaman benih buncis tegak dilakukan pada bulan Maret - Juli 2011. Antar polibag diatur berjarak $20 \mathrm{~cm} \times 40 \mathrm{~cm}$. Pemeliharaan yang dilakukan berupa penyulaman, pemberian pupuk, penyiraman, dan penyiangan gulma. Penyulaman dilakukan sebelum tanaman berumur 10 HST (Hari Setelah Tanam). Pemberian pupuk dilakukan pada saat sebelum tanam dan setiap minggu saat tanaman mulai berumur 2 MST (Minggu Setelah Tanam). Pupuk yang diberikan pada saat dua minggu sebelum tanam adalah urea $0.31 \mathrm{~g}$ polibag $^{-1}$, SP-36 1.25 g polibag $^{-1}$ dan $\mathrm{KCl} 0.45$ g polibag- $^{-}$ ${ }^{1}$. Pupuk tersebut diaplikasikan dengan cara ditabur. Pupuk yang diberikan saat tanaman mulai berumur 2 MST adalah NPK Mutiara dengan konsentrasi $2 \mathrm{~g} \mathrm{~L}^{-1}$ dan diaplikasikan dengan cara dikocor dengan dosis $250 \mathrm{~mL}$ polibag $^{-1}$ tiap minggunya.

Pemanenan pertama dilakukan saat tanaman berusia 53 hari pada bulan April 2011 dan berakhir pada bulan Mei 2011 setelah 9 kali pemanenan. Polong yang dipanen berdasarkan kriteria warna polong agak muda dan suram, permukaan kulitnya agak kasar, biji dan polong belum menonjol, serta polong mengeluarkan bunyi letupan jika dipatahkan (Susila, 2006). Buncis dipanen dengan cara dipetik tangan secara bertahap hingga tanaman tidak menghasilkan polong lagi.

Analisis fisik media tanam yang dilakukan adalah kapasitas memegang air (Water Holding Capacity, WHC), sedangkan analisis kimia media tanam yang dilakukan adalah pengukuran $\mathrm{pH}$ media tanam dan rasio $\mathrm{C} / \mathrm{N}$ media tanam.

Pengamatan dilakukan pada 5 polibag tanaman contoh tiap petak percobaan yang telah dipilih secara acak. Pengamatan pertumbuhan tanaman dilakukan setiap minggu setelah tanam. Pengamatan yang diamati terdiri atas: pengamatan media tanam dan pengamtan tanaman. Pengamatan media tanam dilakukan pada tiga peubah, yaitu : (1) kapasitas memegang air (Water Holding Capacity), (2) pH, dan (3) rasio C/N. Pengamatan tanaman dilakukan pada enam peubah, yaitu: (1) tinggi tanaman (cm), (2) jumlah daun, (3) jumlah cabang, (4) jumlah polong per tanaman dan per petak (polong), (5) bobot polong per tanaman dan per petak $(\mathrm{g})$, dan (6) panjang polong $(\mathrm{cm})$.

\section{HASIL DAN PEMBAHASAN}

\section{Sifat Fisik dan Kimia Media Tanam}

Berdasarkan hasil sidik ragam, perlakuan kombinasi media tanam organik berpengaruh sangat nyata terhadap sifat fisik dan kimia media tanam(Tabel $1)$.

Media tanam limbah media jamur merang (P3) mempunyai nilai kapasitas memegang air yang tertinggi dengan nilai $280.62 \%$, diikuti limbah media jamur tiram (P2) $154.31 \%$. Hasil terendah yaitu media 
Tabel 1. Rekapitulasi sidik ragam sifat fisik dan kimia media tanam organik dan pengaruhnya terhadap pertumbuhan dan produksi buncis tegak (Phaseolus vulgaris L.)

\begin{tabular}{lrc}
\hline Peubah & F-hitung & KK (\%) \\
\hline Kapasitas Memegang Air & $303.81 * *$ & 5.05 \\
(WHC) & & \\
pH & $108.36 * *$ & 1.23 \\
Rasio C/N & $19.96 * *$ & 23.23 \\
Tinggi tanaman (cm) & & \\
1 MST & $6.82 * *$ & 14.07 \\
2 MST & $5.91 * *$ & 9.66 \\
3 MST & $19.86 * *$ & 9.00 \\
4 MST & $62.21 * *$ & 10.49 \\
5 MST & $62.08 * *$ & 9.83 \\
Jumlah cabang (cabang) & & \\
2 MST & $55.25 * *$ & 29.61 \\
3 MST & $52.63 * *$ & 17.12 \\
4 MST & $12.47 * *$ & 29.60 \\
Jumlah daun (helai) & & \\
2 MST & $26.70 * *$ & 30.25 \\
3 MST & $54.25 * *$ & 11.30 \\
4 MST & $93.13 * *$ & 9.41 \\
Jumlah polong per tanaman & $8.49 * *$ & 27.24 \\
Jumlah polong per petak & $12.83 * *$ & 29.29 \\
Bobot polong per tanaman & $16.37 * *$ & 24.37 \\
Bobot polong per petak & $17.29 * *$ & 27.96 \\
Panjang polong & $5.15 * *$ & 6.03 \\
\hline
\end{tabular}

Keterangan: MST $=$ Minggu Setelah Tanam, KK $=$ Koefisien Keragaman, ** berbeda sangat nyata pada Uji DMRT $5 \%$

tanam tanah (P1) dengan nilai 54.38\% (Tabel 2). Hal ini menunjukkan bahwa limbah media jamur merang mampu memegang air dan larutan hara lebih banyak daripada tanah, sehingga cadangan air dalam media tanam tetap tersedia dan mendukung proses penyerapan hara oleh akar. Salah satu peran bahan organik adalah dapat memperbaiki sifat fisik tanah, yaitu meningkatkan kapasitas memegang air (Soepardi, 1983; Hakim et al., 1986; Hanafiah, 2005).

Nilai $\mathrm{pH}$ media tanam pada semua perlakuan berkisar antara 6.4 - 6.9, kecuali pada media tanam tanah (P1) dan pupuk kandang sapi (P4) yang memiliki nilai $\mathrm{pH}$ sekitar 5.4. Nilai $\mathrm{pH}$ tertinggi terdapat pada media tanam limbah media jamur tiram (P2) dengan nilai 6.87 , tidak berbeda nyata dengan nilai $\mathrm{pH}$ media tanam tanah + limbah media jamur merang
+ arang sekam (P11) 6.83 dan tanah + limbah media jamur tiram + limbah media jamur merang + pupuk kandang sapi + arang sekam (P13) 6.73. Nilai pH terendah terdapat pada media tanam tanah $(\mathrm{P} 1)$ dengan nilai 5.37, tidak berbeda nyata dengan $\mathrm{pH}$ pupuk kandang sapi (P4) dengan nilai 5.43. Penambahan bahan organik pada media tanam meningkatkan $\mathrm{pH}$ tanah menjadi mendekati netral (Tabel 2).

Sutanto (2005) menyatakan bahwa kondisi tanah terbaik (tidak mengandung bahan toksik) terjadi pada kondisi agak masam sampai netral (pH 5.0 - 7.5), akan tetapi perbedaan jenis tanaman maupun pola tanam menghendaki kondisi tertentu. Menurut Rubatzky dan Yamaguchi (1998), syarat pH optimum untuk buncis berkisar antara $6.0-6.5$. Dengan demikian nilai $\mathrm{pH}$ pada semua media tanam yang dipakai pada penelitian ini masih dalam kisaran $\mathrm{pH}$ yang tidak mengandung bahan toksik dan dapat diadaptasi oleh tanaman buncis sehingga tanaman buncis masih dapat hidup dan berproduksi.

\section{Pertumbuhan}

Berdasarkan hasil sidik ragam, media tanam organik memberikan pengaruh yang sangat nyata terhadap semua peubah pengamatan pertumbuhan tanaman, yakni tinggi tanaman, jumlah cabang, dan jumlah daun buncis tegak (Tabel 1). Secara umum, respon tinggi tanaman, jumlah cabang, dan jumlah daun buncis tegak terbaik hingga 5 MST terdapat pada empat perlakuan media tanam, yaitu perlakuan media tanam pupuk kandang sapi (P4), tanah + limbah media jamur merang (P6), tanah + limbah media jamur merang + pupuk kandang sapi (P10), dan tanah + limbah media jamur merang + pupuk kandang sapi + arang sekam (P12) (Tabel 3). Hal ini menunjukkan bahwa penggunaan limbah media jamur merang sebagai media tanam campuran dengan tanah (1:1) dan penggunaan pupuk kandang sapi sebagai media tanam tunggal maupun campuran dengan tanah, limbah media jamur merang, dan arang sekam mampu meningkatkan pertumbuhan buncis tegak. Tinggi tanaman buncis tegak pada keempat perlakuan tersebut hingga umur 5 MST telah mendekati tinggi optimum tanaman buncis tegak berdasarkan Balitsa, yaitu $50 \mathrm{~cm}$.

Penambahan bahan organik sebagai komponen media tanam mampu meningkatkan pertumbuhan buncis tegak. Hal tersebut diduga disebabkan oleh peranan bahan organik yang dapat menyumbangkan ion - ion hara tersedia bagi tanaman. Adanya bahan organik juga dapat menghindari terjadinya proses pelindian ion hara oleh aliran massa air. Selain 
Tabel 2. Hasil analisis sifat fisik dan kimia media tanam organik

\begin{tabular}{|c|c|c|c|c|}
\hline No. & Perlakuan & WHC (\%) & $\mathrm{pH}$ & Rasio $\mathrm{C} / \mathrm{N}$ \\
\hline 1 & Tanah & $54.38 \mathrm{i}$ & $5.37 \mathrm{e}$ & 19.86de \\
\hline 2 & $\begin{array}{l}\text { Limbah media } \\
\text { jamur tiram (JT) }\end{array}$ & $154.31 \mathrm{~b}$ & $6.87 \mathrm{a}$ & $68.30 \mathrm{a}$ \\
\hline 3 & $\begin{array}{l}\text { Limbah media } \\
\text { jamur merang } \\
(\mathrm{JM})\end{array}$ & $280.62 \mathrm{a}$ & $6.37 \mathrm{~cd}$ & $14.93 \mathrm{de}$ \\
\hline 4 & $\begin{array}{l}\text { Pupuk kandang } \\
\text { (Pukan) sapi }\end{array}$ & $127.72 \mathrm{c}$ & $5.43 \mathrm{e}$ & $15.04 \mathrm{de}$ \\
\hline 5 & $\begin{array}{l}\text { Tanah + limbah } \\
\text { media JT }\end{array}$ & $109.23 \mathrm{~d}$ & $6.47 \mathrm{c}$ & $47.41 \mathrm{~b}$ \\
\hline 6 & $\begin{array}{l}\text { Tanah + limbah } \\
\text { media JM }\end{array}$ & $79.57 \mathrm{fg}$ & $6.50 \mathrm{c}$ & $19.57 \mathrm{de}$ \\
\hline 7 & $\begin{array}{l}\text { Tanah + limbah } \\
\text { media JT + pukan } \\
\text { sapi }\end{array}$ & $114.88 \mathrm{~d}$ & $6.67 \mathrm{~b}$ & $33.69 \mathrm{c}$ \\
\hline 8 & $\begin{array}{l}\text { Tanah + limbah } \\
\text { media JT + arang } \\
\text { sekam }\end{array}$ & $127.81 \mathrm{c}$ & $6.37 \mathrm{~cd}$ & $60.27 \mathrm{ab}$ \\
\hline 9 & $\begin{array}{l}\text { Tanah + limbah } \\
\text { mediaJT + pukan } \\
\text { sapi }+ \text { arang } \\
\text { sekam }\end{array}$ & $97.14 \mathrm{e}$ & $6.67 \mathrm{~b}$ & $51.91 \mathrm{~b}$ \\
\hline 10 & $\begin{array}{l}\text { Tanah + limbah } \\
\text { media JM + pukan } \\
\text { sapi }\end{array}$ & $67.02 \mathrm{~h}$ & $6.43 \mathrm{~cd}$ & $13.90 \mathrm{e}$ \\
\hline 11 & $\begin{array}{l}\text { Tanah + limbah } \\
\text { media JM + arang } \\
\text { sekam }\end{array}$ & $84.57 \mathrm{f}$ & $6.83 \mathrm{a}$ & $18.06 \mathrm{de}$ \\
\hline 12 & $\begin{array}{l}\text { Tanah + limbah } \\
\text { media JM + pukan } \\
\text { sapi }+ \text { arang } \\
\text { sekam }\end{array}$ & $71.01 \mathrm{gh}$ & $6.30 \mathrm{~d}$ & $19.64 d e$ \\
\hline 13 & $\begin{array}{l}\text { Tanah + limbah } \\
\text { media JT + limbah } \\
\text { media JM + pukan } \\
\text { sapi + arang } \\
\text { sekam }\end{array}$ & $105.82 \mathrm{de}$ & $6.73 \mathrm{ab}$ & $28.96 \mathrm{~cd}$ \\
\hline
\end{tabular}

Keterangan: Angka-angka yang diikuti huruf yang sama pada kolom yang sama tidak berbeda nyata pada taraf $5 \%$ uji DMRT

itu, bahan organik juga dapat memperbaiki struktur tanah sehingga menjadi lebih remah serta dapat meningkatkan kapasitas memegang air dan kapasitas tukar kation (KTK) tanah (Hakim et al., 1986; Hanafiah, 2005).

Berdasarkan hasil analisis media tanam (Tabel 2), nilai kapasitas memegang air media tanam pupuk kandang sapi (P4) 127.72\%, tanah + limbah media jamur merang (P6) 79.57\%, tanah + limbah media jamur merang + pupuk kandang sapi (P10) 67.02\%, dan tanah + limbah media tanam jamur merang + pupuk kandang sapi + arang sekam (P12) 71.01\%, lebih tinggi dibandingkan dengan nilai kapasitas memegang air media tanam tanah (P1) 54.38\%. Kemampuan media tanam dalam memegang air yang tinggi memudahkan proses penyerapan hara dari akar ke tajuk tanaman. Hanafiah (2005) menyatakan bahwa air yang diserap tanaman di samping berfungsi sebagai komponen sel-selnya, juga berfungsi sebagai media reaksi pada hampir seluruh proses metabolismenya. Ion ion hara larut dalam air dan dibawa ke dalam akar kemudian ke daun tanaman.

Air juga menjadi pemicu reaksi kimiawi penyediaan unsur hara yang tidak tersedia menjadi tersedia bagitanaman.Zulkarnain(2010)menambahkan bahwa tanaman yang ditanam pada kadar air mendekati kapasitas lapang akan mampu tumbuh dengan cepat bila unsur hara dan faktor lingkungan lainnya berada dalam kondisi optimal.

Respon pertumbuhan buncis tegak yang baik pada perlakuan media tanam pupuk kandang sapi (P4), tanah + limbah media jamur merang (P6), tanah + limbah media jamur merang + pupuk kandang sapi (P10), dan tanah + limbah media jamur merang + pupuk kandang sapi + arang sekam (P12) juga didukung oleh rasio $\mathrm{C} / \mathrm{N}$ media tanam yang rendah $(<20)$, yaitu 15.04 (P4), 19.57 (P6), 13.90 (P10), dan 19.64 (P12). Hal tersebut menunjukkan bahwa bahan organik dalam keempat perlakuan media tanam tersebut telah terdekomposisi dengan sempurna sehingga unsur hara yang terkandung di dalamnya, khususnya nitrogen, dapat diserap akar tanaman tanpa mengalami persaingan dengan mikroorganisme dekomposer. Salah satu manfaat dari unsur hara nitrogen adalah merangsang pertunasan sehingga jumlah cabang akan semakin banyak dan juga meningkatkan pertumbuhan vegetatif terutama daun (Jumin, 2008). Semakin banyak jumlah daun, diharapkan semakin banyak terjadi fotosintesis yang berguna untuk menghasilkan polong.

\section{Produksi}

Media tanam organik juga memberikan pengaruh yang sangat nyata terhadap semua peubah pengamatan produksi, yakni jumlah polong per tanaman dan per petak, bobot polong per tanaman dan per petak, serta panjang polong (Tabel 1).

Jumlah polong buncis merupakan parameter untuk menentukan kemampuan tanaman buncis dalam berproduksi pada lingkungan tumbuhnya. Jika tanaman mampu menghasilkan polong yang banyak berarti lingkungan tumbuhnya telah sesuai. Penimbangan bobot polong dimaksudkan untuk 
Tabel 3. Pengaruh media tanam organik terhadap pertumbuhan tanaman buncis tegak

\begin{tabular}{|c|c|c|c|c|c|c|c|c|c|c|c|}
\hline \multirow[t]{2}{*}{ No. } & \multirow[t]{2}{*}{ Perlakuan } & \multicolumn{4}{|c|}{ Tinggi Tanaman $(\mathrm{cm})$} & \multicolumn{3}{|c|}{ Jumlah Cabang (cabang) } & \multicolumn{3}{|c|}{ Jumlah daun (helai) } \\
\hline & & $3 \mathrm{MST}$ & & $4 \mathrm{MST}$ & $5 \mathrm{MST}$ & $2 \mathrm{MST}$ & $3 \mathrm{MST}$ & $4 \mathrm{MST}$ & $2 \mathrm{MST}$ & $3 \mathrm{MST}$ & $4 \mathrm{MST}$ \\
\hline 1 & Tanah & 8.7 & $\overline{\mathrm{g}}$ & $11.2 \mathrm{~d}$ & $15.3 \mathrm{~d}$ & $0.0 \mathrm{~d}$ & $1.2 \mathrm{efg}$ & $2.7 \mathrm{def}$ & $0.4 \mathrm{c}$ & $1.8 \mathrm{~cd}$ & $2.9 \mathrm{ef}$ \\
\hline 2 & $\begin{array}{l}\text { Limbah media } \\
\text { jamur tiram ( JT) }\end{array}$ & 9.5 & gf & $10.6 \mathrm{~d}$ & $11.0 \mathrm{~d}$ & $0.0 \mathrm{~d}$ & $0.5 \mathrm{~g}$ & $1.6 \mathrm{f}$ & $0 \mathrm{~d}$ & $0.8 \mathrm{e}$ & $2.0 \mathrm{f}$ \\
\hline 3 & $\begin{array}{l}\text { Limbah media } \\
\text { jamur merang } \\
\text { (JM) }\end{array}$ & 8.8 & $\mathrm{~g}$ & $16.3 \mathrm{c}$ & $22.7 \mathrm{c}$ & $0.0 \mathrm{~d}$ & $1.9 \mathrm{de}$ & $5.6 \mathrm{~cd}$ & $0.3 \mathrm{~cd}$ & $1.8 \mathrm{~cd}$ & $5.0 \mathrm{~d}$ \\
\hline 4 & $\begin{array}{l}\text { Pupuk kandang } \\
\text { (pukan) sapi }\end{array}$ & 15.8 & $\mathrm{a}$ & $36.0 \mathrm{a}$ & $43.4 \mathrm{a}$ & 0.9 a & $6.4 \mathrm{a}$ & $11.1 \mathrm{a}$ & $1.5 \mathrm{a}$ & $4.2 \mathrm{a}$ & $9.7 \mathrm{a}$ \\
\hline 5 & $\begin{array}{l}\text { Tanah + limbah } \\
\text { media JT }\end{array}$ & 10.2 ef & & $11.3 \mathrm{~d}$ & $12.9 \mathrm{~d}$ & $0.0 \mathrm{~d}$ & $0.8 \mathrm{fg}$ & $1.5 \mathrm{f}$ & $0 \mathrm{~d}$ & $1.1 \mathrm{e}$ & $2.2 \mathrm{f}$ \\
\hline 6 & $\begin{array}{l}\text { Tanah + limbah } \\
\text { media JM }\end{array}$ & 16.1 & $\mathrm{a}$ & $37.8 \mathrm{a}$ & $43.7 \mathrm{a}$ & $0.8 \mathrm{ab}$ & $5.0 \mathrm{~b}$ & $9.8 \mathrm{ab}$ & $1.3 \mathrm{ab}$ & $3.5 \mathrm{~b}$ & $8.7 \mathrm{~b}$ \\
\hline 7 & $\begin{array}{l}\text { Tanah }+ \text { limbah } \\
\text { media JT }+ \\
\text { pukan sapi }\end{array}$ & $12.5 \mathrm{cc}$ & & $17.5 \mathrm{c}$ & $22.6 \mathrm{c}$ & $0.1 \mathrm{~d}$ & $1.6 \mathrm{def}$ & $3.6 \mathrm{def}$ & $0.2 \mathrm{~cd}$ & $1.7 \mathrm{~d}$ & $3.5 \mathrm{e}$ \\
\hline 8 & $\begin{array}{l}\text { Tanah + limbah } \\
\text { media JT + arang } \\
\text { sekam }\end{array}$ & 9.1 & g & $10.4 \mathrm{~d}$ & $12.8 \mathrm{~d}$ & $0.0 \mathrm{~d}$ & $0.6 \mathrm{~g}$ & $2.1 \mathrm{ef}$ & $0.2 \mathrm{~cd}$ & $1.2 \mathrm{e}$ & $2.1 \mathrm{f}$ \\
\hline 9 & $\begin{array}{l}\text { Tanah + limbah } \\
\text { media JT }+ \\
\text { pukan sapi }+ \\
\text { arang sekam }\end{array}$ & $11.1 \mathrm{de}$ & & $19.7 \mathrm{c}$ & $28.0 \mathrm{~b}$ & $0.0 \mathrm{~d}$ & $2.2 \mathrm{~d}$ & $4.8 \mathrm{cde}$ & $0.3 \mathrm{~cd}$ & $2.0 \mathrm{~cd}$ & $5.0 \mathrm{~d}$ \\
\hline 10 & $\begin{array}{l}\text { Tanah + limbah } \\
\text { media JM + } \\
\text { pukan sapi }\end{array}$ & 15.9 & $\mathrm{a}$ & $36.6 \mathrm{a}$ & $41.8 \mathrm{a}$ & $0.9 \mathrm{a}$ & $5.1 \mathrm{~b}$ & $9.6 \mathrm{ab}$ & $1.2 \mathrm{~b}$ & $4.0 \mathrm{a}$ & $9.1 \mathrm{ab}$ \\
\hline 11 & $\begin{array}{l}\text { Tanah + limbah } \\
\text { media JM + } \\
\text { arang sekam }\end{array}$ & $13.2 \mathrm{~b}$ & & $28.0 \mathrm{~b}$ & $32.6 \mathrm{~b}$ & $0.6 \mathrm{c}$ & $4.1 \mathrm{c}$ & $5.7 \mathrm{~cd}$ & $1.0 \mathrm{~b}$ & $3.1 \mathrm{~b}$ & $7.6 \mathrm{c}$ \\
\hline 12 & $\begin{array}{l}\text { Tanah + limbah } \\
\text { media JM + } \\
\text { pukan sapi }+ \\
\text { arang sekam }\end{array}$ & $14.5 \mathrm{al}$ & $a b$ & $34.4 \mathrm{a}$ & $40.6 \mathrm{a}$ & $0.7 \mathrm{bc}$ & $4.9 \mathrm{~b}$ & $7.3 \mathrm{bc}$ & $1.1 \mathrm{~b}$ & $3.2 \mathrm{~b}$ & $8.6 \mathrm{~b}$ \\
\hline 13 & $\begin{array}{l}\text { Tanah + limbah } \\
\text { media JT + } \\
\text { limbah media } \\
\text { JM + pukan } \\
\text { sapi + arang } \\
\text { sekam }\end{array}$ & $11.7 \mathrm{~cd}$ & & $24.6 \mathrm{~b}$ & $32.4 \mathrm{~b}$ & $0.0 \mathrm{~d}$ & $2.4 \mathrm{~d}$ & $4.3 \mathrm{cdef}$ & $0.2 \mathrm{~cd}$ & $2.2 \mathrm{c}$ & $5.4 \mathrm{~d}$ \\
\hline
\end{tabular}

Keterangan: Angka-angka yang diikuti huruf yang sama pada kolom yang sama tidak berbeda nyata pada taraf $5 \%$ uji DMRT

mengetahui produksi yang dihasilkan dari masingmasing perlakuan media tanam.

Persentase peningkatan hasil tanaman buncis tegak yang ditanam pada media tanam organik menunjukkan bahwa penggunaan bahan organik sebagai komponen media tanam secara umum mampu meningkatkan hasil tanaman buncis tegak dibandingkan media tanam tanah (Tabel 4). Penambahan limbah media jamur merang dapat meningkatkan hasil bobot polong per tanaman buncis tegak sebanyak $250-500 \%$, sedangkan hasil bobot per petak meningkat sebanyak $300-600 \%$. Penambahan pupuk kandang sapi dapat meningkatkan hasil bobot polong per tanaman sebanyak $90-300 \%$, sedangkan hasil bobot polong per petak meningkat sebanyak 100 - 300\%. Peningkatan hasil pada penambahan bahan organik sebagai komponen media tanam diduga karena peran bahan organik yang sangat baik dalam memperbaiki sifat fisik, kimia, dan biologi tanah sehingga menunjang produksi tanaman buncis tegak. Adapun penurunan persentase hasil pada media tanam yang mengandung komponen limbah media jamur tiram 
diduga karena proses dekomposisi limbah media jamur tiram yang belum sempurna sehingga menghambat pertumbuhan dan produksi tanaman buncis tegak.

Nilai panjang polong buncis terbaik dari ketiga perlakuan (P3, P10, P12) belum mencapai panjang polong sesuai deskripsi varietas buncis tegak, yaitu $13 \mathrm{~cm}$ (Tabel 4). Djuariah (2008) menyatakan bahwa panjang polong dan diameter polong buncis akan lebih kecil pada dataran yang lebih rendah dibandingkan dengan dataran yang lebih tinggi. Hal ini diduga karena lingkungan tempat tumbuh yang kurang optimal. Meskipun belum mencapai panjang polong sesuai deskripsi varietas, panjang polong buncis tegak yang ditanam pada media tanam organik mampu mendekati deskripsi varietas dibandingkan perlakuan media tanah dan limbah media jamur tiram sebagai media tanam tunggal. Hal tersebut menunjukkan bahwa penambahan bahan organik sebagai komponen media tanam tidak hanya dapat meningkatkan produksi buncis secara kuantitas, tetapi juga secara kualitas, dilihat dari panjang polong buncis tegak

Berdasarkan hasil jumlah dan bobot polong tanaman buncis tegak pada berbagai media tanam organik, semua tanaman buncis tegak dapat tumbuh dan berproduksi (Tabel 4). Hasil rata - rata jumlah dan bobot polong per tanaman serta jumlah dan bobot polong per petak terbanyak terdapat pada perlakuan media tanam limbah media jamur merang (P3) dan secara umum disusul dengan perlakuan media tanam pupuk kandang sapi (P4), tanah + limbah media jamur merang (P6), tanah + limbah media jamur merang + pupuk kandang sapi (P10), dan tanah + limbah media jamur merang + pupuk kandang sapi + arang sekam (P12).

Tabel 4. Pengaruh media tanam organik terhadap produksi buncis tegak dan persentase peningkatan bobot polong dibandingkan dengan tanah

\begin{tabular}{|c|c|c|c|c|c|c|c|c|}
\hline No. & Perlakuan & $\begin{array}{c}\text { Jumlah } \\
\text { polong } \\
\text { tanaman-1 }\end{array}$ & $\begin{array}{c}\text { Bobot } \\
\text { polong } \\
\text { tanaman-1 } \\
(\mathrm{g})\end{array}$ & $\begin{array}{l}\text { Persentase } \\
\text { peningkatan } \\
(\%)\end{array}$ & $\begin{array}{l}\text { Jumlah } \\
\text { polong } \\
\text { petak-1 }\end{array}$ & $\begin{array}{l}\text { Bobot } \\
\text { polong } \\
\text { petak-1 }\end{array}$ & $\begin{array}{l}\text { Persentase } \\
\text { peningkatan } \\
\quad(\%)\end{array}$ & $\begin{array}{l}\text { Panjang } \\
\text { polong } \\
(\mathrm{cm})\end{array}$ \\
\hline 1 & Tanah & $2.1 \mathrm{~d}$ & $5.40 \mathrm{de}$ & - & $11.1 \mathrm{ef}$ & $32.32 \mathrm{~cd}$ & - & $9.77 \mathrm{bc}$ \\
\hline 2 & $\begin{array}{l}\text { Limbah media jamur } \\
\text { tiram }(\mathrm{JT})\end{array}$ & $2.8 \mathrm{~cd}$ & $5.71 \mathrm{de}$ & 5.74 & $3.5 \mathrm{f}$ & $7.95 \mathrm{~d}$ & -76.33 & $9.00 \mathrm{c}$ \\
\hline 3 & $\begin{array}{l}\text { Limbah media jamur } \\
\text { merang }(\mathrm{JM})\end{array}$ & $8.2 \mathrm{a}$ & $33.90 \mathrm{a}$ & 527.78 & $65.4 \mathrm{a}$ & $254.69 \mathrm{a}$ & 688.03 & $11.40 \mathrm{a}$ \\
\hline 4 & $\begin{array}{l}\text { Pukan (pupuk } \\
\text { kandang) sapi }\end{array}$ & $7.2 \mathrm{a}$ & $23.00 \mathrm{~b}$ & 325.93 & $41.4 \mathrm{bc}$ & $153.85 \mathrm{~b}$ & 376.02 & $10.57 \mathrm{ab}$ \\
\hline 5 & $\begin{array}{l}\text { Tanah + limbah media } \\
\text { JT }\end{array}$ & $1.7 \mathrm{~d}$ & $3.27 \mathrm{e}$ & -39.44 & $4.8 \mathrm{f}$ & $9.11 \mathrm{~d}$ & -71.81 & $9.17 \mathrm{c}$ \\
\hline 6 & $\begin{array}{l}\text { Tanah + limbah media } \\
\text { JM }\end{array}$ & $7.9 \mathrm{a}$ & $26.26 \mathrm{ab}$ & 386.30 & $51.9 \mathrm{ab}$ & $174.20 \mathrm{~b}$ & 438.99 & $11.00 \mathrm{ab}$ \\
\hline 7 & $\begin{array}{l}\text { Tanah + limbah media } \\
\text { JT + pukan sapi }\end{array}$ & $3.0 \mathrm{bcd}$ & $10.54 \mathrm{de}$ & 95.19 & $20.1 \mathrm{def}$ & $67.53 \mathrm{c}$ & 108.94 & $10.80 \mathrm{ab}$ \\
\hline 8 & $\begin{array}{l}\text { Tanah + limbah media } \\
\text { JT + arang sekam }\end{array}$ & $2.3 \mathrm{~d}$ & $4.58 \mathrm{de}$ & -15.19 & $8.5 \mathrm{f}$ & $30.48 \mathrm{~cd}$ & -5.69 & $9.10 \mathrm{c}$ \\
\hline 9 & $\begin{array}{l}\text { Tanah + limbah media } \\
\text { JT }+ \text { pukan sapi }+ \\
\text { arang sekam }\end{array}$ & $4.1 \mathrm{bcd}$ & $12.29 \mathrm{~cd}$ & 127.59 & $27.3 \mathrm{cde}$ & $73.94 \mathrm{c}$ & 128.77 & $10.40 \mathrm{ab}$ \\
\hline 10 & $\begin{array}{l}\text { Tanah + limbah media } \\
\mathrm{JM}+\text { pukan sapi }\end{array}$ & $7.2 \mathrm{a}$ & $26.50 \mathrm{ab}$ & 390.74 & $47.8 \mathrm{~b}$ & $173.23 \mathrm{~b}$ & 435.98 & $11.10 \mathrm{a}$ \\
\hline 11 & $\begin{array}{l}\text { Tanah + limbah media } \\
\mathrm{JM}+\text { arang sekam }\end{array}$ & $5.6 \mathrm{ab}$ & $20.08 \mathrm{bc}$ & 271.85 & $36.3 \mathrm{bcd}$ & $160.95 \mathrm{~b}$ & 397.99 & $10.90 \mathrm{ab}$ \\
\hline 12 & $\begin{array}{l}\text { Tanah + limbah media } \\
\mathrm{JM}+\text { pukan sapi }+ \\
\text { arang sekam }\end{array}$ & $7.1 \mathrm{a}$ & $21.10 \mathrm{~b}$ & 290.74 & $42.9 \mathrm{bc}$ & $134.11 \mathrm{~b}$ & 314.94 & $11.57 \mathrm{a}$ \\
\hline 13 & $\begin{array}{l}\text { Tanah + limbah media } \\
\text { JT + limbah media JM } \\
+ \text { pukan sapi + arang } \\
\text { sekam }\end{array}$ & $5.5 \mathrm{abc}$ & $19.12 b c$ & 254.07 & $37.4 \mathrm{bc}$ & $135.44 b$ & 319.06 & $10.77 \mathrm{ab}$ \\
\hline
\end{tabular}

Keterangan: Angka-angka yang diikuti huruf yang sama pada kolom yang sama tidak berbeda nyata pada taraf $5 \%$ uji DMRT, No. = Nomor 
Tabel 5. Koefisien korelasi rasio $\mathrm{C} / \mathrm{N}$ terhadap produksi buncis tegak

\begin{tabular}{llllll}
\hline & $\begin{array}{c}\text { Jumlah polong } \\
\text { tanaman-1 }\end{array}$ & $\begin{array}{c}\text { Jumlah polong } \\
\text { petak-1 }\end{array}$ & $\begin{array}{c}\text { Bobot polong } \\
\text { tanaman-1 }\end{array}$ & $\begin{array}{c}\text { Bobot polong } \\
\text { petak-1 }\end{array}$ & $\begin{array}{c}\text { Panjang } \\
\text { polong }\end{array}$ \\
\hline Koefisien korelasi & -0.622 & -0.672 & -0.663 & -0.704 & -0.586 \\
$\operatorname{Pr}<\mathrm{F}$ & $<.0001$ & $<.0001$ & $<.0001$ & $<.0001$ & 0.000 \\
\hline
\end{tabular}

Pada kelima perlakuan yang menghasilkan pertumbuhan dan produksi buncis tegak yang baik terdapat komponen limbah media jamur merang (P3) dan pupuk kandang sapi (P4) maupun campuran dari keduanya (P6, P10, P12). Hasil analisis kimia media tanam organik menunjukkan bahwa nilai rasio $\mathrm{C} / \mathrm{N}$ limbah media tanam jamur merang (P3) rendah (14.93), demikian juga dengan rasio $\mathrm{C} / \mathrm{N}$ pupuk kandang sapi (P4) 15.04. Nilai rasio $\mathrm{C} / \mathrm{N}$ kedua jenis media tanam tersebut mendekati rasio $\mathrm{C} / \mathrm{N}$ tanah $(8-15$, umumnya $10-12)$. Setyorini et al. (2006) menyatakan bahwa apabila bahan organik mempunyai rasio $\mathrm{C} / \mathrm{N}$ mendekati atau sama dengan rasio $\mathrm{C} / \mathrm{N}$ tanah, maka bahan tersebut dapat digunakan oleh tanaman. Dengan demikian unsur hara yang terkandung di dalam limbah media jamur merang dan pupuk kandang sapi dapat tersedia dan diserap oleh akar tanaman secara optimal.

Nilai koefisien korelasi berkisar antara -1 dan $1(-1 \leq \mathrm{r} \leq 1)$. Nilai $\mathrm{r}$ yang mendekati 1 atau -1 menunjukkan semakin erat hubungan linier antara kedua peubah, sedangkan nilai $\mathrm{r}$ yang mendekati nol menggambarkan hubungan kedua peubah tersebut tidak linier (Mattjik dan Sumertajaya, 2002).

Rasio $\mathrm{C} / \mathrm{N}$ juga berpengaruh sangat nyata terhadap bobot polong per tanaman maupun per petak. Nilai koefisien determinasi $\left(\mathrm{R}^{2}\right)$ untuk bobot polong per tanaman dan per petak masing - masing 0.44 dan 0.496. Berdasarkan nilai tersebut berarti koefisien korelasinya adalah 0.66 dan 0.70 dengan tanda negatif (Tabel 5). Tingkat keeratan hubungan antara rasio $\mathrm{C} /$ $\mathrm{N}$ dan kedua peubah kurang kuat, di mana peningkatan rasio $\mathrm{C} / \mathrm{N}$ diikuti oleh penurunan bobot polong per tanaman maupun per petak.

Hasil analisis korelasi rasio $\mathrm{C} / \mathrm{N}$ terhadap panjang polong buncis tegak menunjukkan bahwa nilai koefisien determinasinya 0.338 sehingga didapat nilai koefisien korelasinya 0.58 dan bertanda negatif (Tabel 5). Tingkat keeratan hubungan antara rasio $\mathrm{C} /$ $\mathrm{N}$ dan panjang polong tidak kuat, di mana kenaikan rasio $\mathrm{C} / \mathrm{N}$ diikuti oleh penurunan panjang polong atau semakin rendah rasio $\mathrm{C} / \mathrm{N}$ maka semakin tinggi nilai panjang polong buncis tegak.

Berdasarkan hasil analisis korelasi rasio $\mathrm{C} /$ $\mathrm{N}$ media tanam organik terhadap produksi buncis tegak, dapat disimpulkan bahwa tingkat hubungan linier antara dua peubah tersebut kurang kuat dan berkorelasi negatif, artinya semakin rendah rasio $\mathrm{C} / \mathrm{N}$ media tanam maka akan semakin tinggi produksi buncis tegak pada peubah pengamatan jumlah polong per tanaman dan per petak, bobot polong per tanaman dan per petak, dan panjang polong buncis tegak, khususnya pada perlakuan limbah media jamur merang (P3), pupuk kandang sapi (P4), tanah + limbah media jamur merang (P6), tanah + limbah media jamur merang + pupuk kandang sapi (P10), dan tanah + limbah media jamur merang + pupuk kandang sapi + arang sekam (P12). Pertumbuhan dan produksi buncis tegak yang baik dapat didukung oleh media tanam yang memiliki rasio $\mathrm{C} / \mathrm{N}$ yang rendah, yakni sekitar $13-20$. Hasil polong pada kelima perlakuan (P3, P4, P6, P10, P12) yang tinggi didukung oleh kapasitas memegang air yang tinggi pula pada limbah media jamur merang (280.62\%) dan pupuk kandang sapi (127.72\%) sehingga mendukungproses penyerapan hara oleh akar tanaman. Dengan demikian, penggunaan limbah media jamur merang dan pupuk kandang sapi sebagai salah satu komponen campuran pada perlakuan media tanam dapat memberikan pengaruh yang baik pada hasil polong buncis tegak. Hasil korelasi kapasitas memegang air terhadap produksi buncis tegak Jumlah polong per petak pada media tanam pupuk kandang sapi (P4) tidak memberikan hasil yang terbaik meskipun jumlah cabang dan daunnya memberikan hasil terbaik. Hal tersebut diduga karena kandungan nitrogen dalam pupuk kandang sapi yang lebih tinggi daripada kandungan fosfor sehingga pertumbuhan vegetatifnya lebih baik daripada generatifnya. Pada umumnya pupuk kandang sapi mengandung nitrogen (N) $2-8 \%$, fosfor (P2O5) $0.2-1 \%$, kalium (K2O) 1 - 3\%, magnesium $(\mathrm{Mg}) 1.0$ - $1.5 \%$, dan unsur mikro (Donahue et al., 1977).

Berdasarkan nilai hasil terbaik, produksi bobot polong per tanaman pada perlakuan media tanam limbah media jamur merang (P3), yakni 33.90 $\mathrm{g} \operatorname{tanaman}^{-1}$, dapat dihitung hasil polong buncis tegak yang ditanam pada perlakuan limbah media jamur merang (P3) yaitu $423.75 \mathrm{~g} \mathrm{~m}^{2-1}$ atau sekitar $0.42 \mathrm{~kg} \mathrm{~m}^{2-1}$ (4.24 ton ha-1). Jika dibandingkan dengan potensi hasil buncis tegak berdasarkan Balitsa, yakni 
\pm 20 ton $\mathrm{ha}^{-1}$ atau sekitar $2 \mathrm{~kg} \mathrm{~m}^{2-1}$, maka hasil tanaman buncis tegak yang ditanam pada media tanam limbah media jamur merang (P3) baru dapat mencapai sekitar 21\% dari potensi produksi Balitsa. Akan tetapi jika dibandingkan dengan produksi nasional pada tahun 2010 (9.22 ton $\left.\mathrm{ha}^{-1}=0.922 \mathrm{~kg} \mathrm{~m}^{-1}\right)$, maka hasil tanaman buncis tegak yang ditanam pada media tanam limbah media jamur merang (P3) dapat mencapai sekitar $46 \%$ dari produksi nasional tahun 2010. Adapun jika dibandingkan dengan deskripsi produksi berdasarkan Prosea, yakni 5 ton ha-1, maka hasil tanaman buncis tegak yang ditanam pada limbah media jamur merang (P3) dapat mencapai sekitar 84\% dari produksi berdasarkan Prosea.

Hasil polong tanaman buncis tegak yang rendah dapat disebabkan oleh beberapa faktor, diduga salah satunya adalah faktor suhu udara. Pada penelitian ini, rata - rata suhu udara pada saat muncul bunga (6 MST) adalah $25.4^{\circ} \mathrm{C}$ namun pada masa pembentukan polong (7 MST) suhu udara meningkat menjadi $\pm 25.9^{\circ} \mathrm{C}$. Putrasamedja (1992) menyatakan bahwa khusus untuk pembentukan polong buncis memerlukan suhu di bawah $25^{\circ} \mathrm{C}$ karena pada suhu sekitar $26-28^{\circ} \mathrm{C}$ banyak bunga yang gugur sebelum terjadi penyerbukan. Djuariah (2008) juga menambahkan bahwa suhu udara di atas $25^{\circ} \mathrm{C}$ tidak baik untuk pembentukan buah, begitu pula jika suhu udara dingin tidak baik untuk pertumbuhan maupun pembuahan. Selain faktor suhu udara, rendahnya hasil buncis tegak diduga karena lingkungan tumbuhnya yang terbatas. Pada penelitian ini buncis tegak ditanam dalam wadah polibag sehingga unsur hara dan daya sokong media tanamnya terbatas. Dole dan Wilkins (2005) menyatakan bahwa tanaman yang tumbuh dalam wadah kurang memiliki ketersediaan air dan hara serta drainase yang terbatas.

\section{KESIMPULAN}

Secara umum, media tanam pupuk kandang sapi (P4), tanah + limbah media jamur merang (P6), tanah + limbah media jamur merang + pupuk kandang sapi (P10), dan tanah + limbah media jamur merang + pupuk kandang sapi + arang sekam (P12) memberikan pengaruh yang baik pada pertumbuhan dan produksi buncis tegak, namun respon produksi buncis tegak yang terbaik diberikan oleh media tanam limbah media jamur merang (P3).

Ada hubungan linier antara rasio $\mathrm{C} / \mathrm{N}$ dan produksi buncis tegak di mana korelasi keduanya bernilai negatif. Semakin rendah rasio $\mathrm{C} / \mathrm{N}$ maka akan semakin tinggi produksi buncis tegak.

Penambahan limbah media jamur merang sebagai komponen media tanam mampu meningkatkan produksi buncis tegak hingga 600\% dibandingkan dengan media tanam tanah, namun belum dapat mencapai potensi produksi buncis nasional.

\section{DAFTAR PUSTAKA}

Asandhi, A.A., N. Nurtika, N. Sumarni. 2005. Optimasi pupuk dalam usahatani LEISA bawang merah di dataran rendah. J. Hort. 15(3):199-207.

Badan Pusat Statistik Republik Indonesia. 2011. Produksi sayuran di Indonesia. http:// ww w.bps.go.id. [30 Oktober 2011].

Balai Penelitian Tanaman Sayuran. 2006. Calon Varietas Unggul Buncis Tegak. Balai Penelitian Tanaman Sayuran. Bandung.

Djuariah, D. 2008. Penampilan lima kultivar kacang buncis tegak di dataran rendah. J. Agrivigor 8(1):64-73.

Dole, J.M., H.F. Wilkins. 2005. Floriculture: Principles and Species. Prentice Hall, Upper Saddle River. New Jersey.

Donahue, R.L., R.W. Miller, J.C. Shickluna. 1977. An Introduction to Soil and Plant Growth. 4 Ed. Prentice Hall, Inc. New Jersey.

Hakim, N., M.Y. Nyakpa, A.M. Lubis, S.G.Nugroho, M.A. Diha, Go, B.H., dan H.H. Bailey. 1986. Dasar - dasar Ilmu Tanah. Universitas Lampung. Lampung. 488 hal.

Hanafiah, K.A. 2005. Dasar - dasar Ilmu Tanah. Rajawali Pers. Jakarta.

Harjadi, S.S. 1989. Dasar-dasar Hortikultura. Jurusan Budidaya Pertanian, Fakultas Pertanian. Institut Pertanian Bogor. Bogor.

Hartutik, S., Sriatun, Taslimah. 2008. Pembuatan pupuk kompos dari limbah bunga kenanga dan pengaruh persentase zeolit terhadap ketersediaan nitrogen tanah. http://www. eprints.undip.ac.id. [26 Oktober 2011].

Jumin, H.B. 2008. Dasar-dasar Agronomi. PT Raja Grafindo Persada. Jakarta.

Mattjik, A.A., M. Sumertajaya. 2002. Perancangan Percobaan dengan Aplikasi SAS dan Minitab; Jilid 1. IPB Press. Bogor.

Nurwati, S.R. 2011. Pemanfaatan limbah baglog jamur sebagai media budidaya cacing Pheretima sp. Tesis. Magister Teknik Sistem FT. UGM. Yogyakarta. 
Putrasamedja, S. 1992. Adaptasi berbagai macam kacang buncis tipe tegak (Phaseolus vulgaris L.) di dataran rendah. Bul. Penel. Hort. XXII(2):5-9.

Rubatzky, V.E., M. Yamaguchi. 1998. Sayuran Dunia 2: Prinsip, Produksi, dan Gizi, Jilid 2 (diterjemahkan dari: World Vegetable: Principles, Production, and Nutritive, Second Edition, penerjemah: Catur Herison). Penerbit ITB. Bandung. 292 hal.

Setyorini, D., R. Saraswati, E.K. Anwar. 2006. Kompos. h. 11-40. Dalam R.D.M. Simanungkalit, D.A. Suriadikarta, R. Saraswati, D. Setyorini, dan W. Hartatik (Eds.). Pupuk Organik dan Pupuk Hayati: Organic Fertilizer and Biofertilizer. Balai Besar Penelitian dan Pengembangan Sumberdaya Lahan Pertanian. Bogor.

Smartt, J. 1992. Phaseolus vulgaris L., p. 60-63. In L.J.G. van der Maesen and S. Somaatmadja (Eds.). Plant Resources of South-East Asia (Prosea); No 1; Pulses. Bogor.
Soepardi, G. 1983. Sifat dan Ciri Tanah. Institut Pertanian Bogor. Bogor.

Susila, A.D. 2006. Panduan Budidaya Tanaman Sayuran. Departemen Agronomi dan Hortikultura IPB. Bogor.

Sutanto, R. 2005. Dasar-dasar Ilmu Tanah; Konsep dan Kenyataan. Kanisius. Yogyakarta. 208 hal.

Yuliastuti, E., A. Susilo. 2003. Studi kandungan nutrisi limbah media tanam jamur tiram putih (Pleurotus ostreatus) untuk pakan ternak ruminansia. http://pk.ut.ac.id. [Desember 2010].

Zulkarnain. 2010. Dasar - dasar Hortikultura. Bumi Aksara. Jakarta. 